\title{
Ethnicity and Geographic Distribution of Pediatric Chronic Ataxia in Manitoba
}

\author{
Michael S. Salman, Shaheen Masood, Meghan Azad, Bernard N. Chodirker
}

\begin{abstract}
Background: Genetic and environmental factors are important determinants of disease distribution. Several disorders associated with ataxia are known to occur more commonly in certain ethnic groups; for example, the disequilibrium syndrome in the Hutterites. The aim of this study was to determine the ethnic and geographic distribution of pediatric patients with chronic ataxia in Manitoba, Canada. Methods: We identified 184 patients less than 17 years-of-age with chronic ataxia during 1991-2008 from multiple sources. Their diagnosis, ethnicity and place of residence were determined following a chart review. Results: Most patients resided in Manitoba ( $\mathrm{N}=177)$ and the majority in Winnipeg, the provincial capital. Thirty five Aboriginal, 29 Mennonite and 11 Hutterite patients resided in Manitoba. The latter two groups were significantly overrepresented in our cohort. Ataxia telangiectasia, mitochondrial disorders, and non-progressive ataxia of unknown etiology associated with pyramidal tracts signs and developmental delay were significantly more common in Mennonite patients. Four of five patients with neuronal migration disorders associated with chronic ataxia were Aboriginal. Few isolated disorders with chronic ataxia occurred in the 11 Hutterite patients including a Joubert syndrome related disorder. Conclusions: Three disorders associated with chronic ataxia were more prevalent than expected in Mennonites in Manitoba. Few rare disorders were more prevalent in the Hutterite and Aboriginal population. Further research is needed to determine the risk factors underlying these variations in prevalence within different ethnic groups. The unique risk factor profiles of each ethnic group need to be considered in health promotion endeavors.
\end{abstract}

RÉSUMÉ: Ethnie et distribution géographique de l'ataxie chronique chez des patients d'âge pédiatrique au Manitoba. Contexte : Les facteurs génétiques et environnementaux sont des déterminants importants de la répartition d'une maladie dans une population. Il est bien connu que plusieurs maladies comportant de l'ataxie surviennent plus fréquemment dans certaines ethnies, comme par exemple le syndrome de déséquilibre chez les communautés huttériennes. Le but de cette étude était de déterminer la distribution ethnique et géographique des patients pédiatriques atteints d'ataxie chronique au Manitoba, Canada. Méthode : Nous avons identifié 184 patients de moins de 17 ans atteints d'ataxie chronique entre 1991 et 2008 . Nos sources de renseignements étaient multiples. Le diagnostic, l'ethnie et le lieu de résidence étaient obtenus du dossier médical. Résultats : La plupart des patients résidaient au Manitoba $(\mathrm{n}=177)$ et la majorité habitait Winnipeg, la capitale provinciale. Trente-cinq patients autochtones, 29 mennonites et 11 huttériens résidaient au Manitoba. Ces deux derniers groupes étaient significativement surreprésentés dans notre cohorte de patients. L'ataxietéléangiectasie, les maladies mitochondriales et l'ataxie non évolutive d'étiologie inconnue associée à des signes pyramidaux et à un retard du développement étaient significativement plus fréquentes chez les patients mennonites. Quatre des 5 patients atteints de troubles de la migration neuronale associé à une ataxie chronique étaient des Autochtones. Peu de maladies isolées avec ataxie chronique ont été observées chez les 11 Huttériens, incluant une maladie liée au syndrome de Joubert. Conclusions : Trois maladies comportant une ataxie chronique avaient une prévalence plus élevée que prévu chez les Mennonites du Manitoba. La prévalence de quelques maladies rares était plus élevée dans les populations huttérienne et autochtone. On devra procéder à des recherches plus poussées pour déterminer les facteurs de risque sous-jacents à ces variations de la prévalence au sein de différents groupes ethniques. Le profil de facteurs de risque unique à chaque groupe ethnique doit être pris en compte lors de campagnes de promotion de la santé.

Can J Neurol Sci. 2014; 41: 29-36

Genetic and environmental factors are important determinants of disease frequency and distribution. ${ }^{1,2}$ Several inherited disorders are more commonly seen in certain ethnic groups, for example carnitine palmitoyltransferase type 1a in the Canadian Aboriginal population, 3,4 and maple syrup urine disease in the Mennonite population..$^{5}$ The high incidence of genetic diseases among specific ethnic groups is important in health care planning. ${ }^{4-6}$ In addition, understanding ethnic differences and associated risk factors for various disorders is important in planning appropriate prevention strategies. ${ }^{5}$

Ataxia is characterized by incoordination and inability to maintain balance. Ataxia is clinically and etiologically a heterogeneous group of disorders. ${ }^{7}$ Several disorders associated with ataxia are known to occur more commonly in geographic or ethnic clusters. ${ }^{1,8-11}$ The Canadian population is ethnically diverse because of migration. During the last few decades a

From the Section of Pediatric Neurology (MSS, SM), Section of Genetics and Metabolism (BNC), Department of Pediatrics and Child Health (MSS, BNC), Faculty of Medicine, University of Manitoba, Winnipeg, Manitoba; and Department of Pediatrics (MA), University of Alberta, Edmonton, Alberta; Canada.

Received March 18, 2013. Final Revisions Submitted July 5, 2013. Correspondence to: Michael S. Salman, Section of Pediatric Neurology, Children's Hospital, AE 308, 820 Sherbrook Street, Winnipeg, Manitoba, R3A 1R9, Canada. Email: msalman@hsc.mb.ca. 
number of new genetic causes of ataxia have been described in discrete ethnic groups within Canada and elsewhere. ${ }^{8,12,13}$ Previously, we have identified 184 pediatric patients with chronic ataxia in Manitoba, Canada. Patients with ataxia caused solely by brain tumors, peripheral nervous system diseases and vestibular system dysfunction were excluded. Angelman syndrome, ataxia telangiectasia and mitochondrial disorders were the most common etiologies in our cohort. ${ }^{14}$

The aims of this study were to describe the ethnic and geographic distribution of pediatric patients presenting with chronic ataxia in Manitoba and to ascertain if any clustering of diseases associated with pediatric chronic ataxia occurs in the province; specifically in the Mennonite, Hutterite, and Aboriginal populations who are minority groups in Manitoba that are known to have a higher prevalence of genetic disorders.

\section{Methods}

We searched several databases and clinical information resources to identify pediatric patients with chronic ataxia, who received care at Winnipeg Children's Hospital between 1991 and 2008. Further details on the methodology, including ascertainment of the patients are described elsewhere. ${ }^{14}$ Patients from neighboring provinces whose health needs are served by our tertiary pediatric hospital were also included in the initial search. In the analysis, only patients resident in Manitoba were investigated for ethnic and geographic clustering.

Ethical approval for the study was granted by the Research Ethics Board of the University of Manitoba. Data were collected from the patients' hospital medical charts including age, gender, place of birth, place of residence, and etiology as described previously. ${ }^{14}$ As part of routine clinical practice, parents are asked about their ethnic background during the patient assessment. The information is usually documented in the neurology and genetics/metabolic charts. Data pertaining to ethnic groups were extracted and defined according to the following categories: Mennonite, Hutterite, Caucasian (excluding Mennonites and Hutterites), Asian, Indian, African/ Caribbean, mixed, or Aboriginal and if known: First Nation, Metis, or Inuit.

The inclusion criteria were:

1. The age of the patients on presentation was less than 17 years.

2. The ataxia was chronic (i.e. greater than two months long or intermittent with two or more discrete episodes of ataxia) during any period between birth and 16 years-of-age.

3. The patients attended Winnipeg Children's Hospital, the only tertiary pediatric hospital in the province of Manitoba, to assess and investigate their ataxia.

4. The patients presented between 1991 and 2008.

The exclusion criteria were:

1. Patients whose ataxia was not an important clinical feature (i.e. not clinically significant and not affecting day to day life).

2. A single episode of ataxia that fully recovered within two months of onset and never recurred.
3. Ataxia caused only by diseases of the peripheral nerves, vestibular system, or primary brain tumors.

4. Patients who were clumsy or had developmental coordination disorder but were not ataxic.

Disease etiology and ethnicity were then investigated to identify any disease clustering. This information was compared to the population at risk (children residing in Manitoba) obtained from provincial census data.

Statistics Canada conducts a population census once every five years. Data on ethnicity and religion are available by various age groups including children less than 15 years and youth aged 15-24 years. Ethnicity is documented in every census, but religion (used to identify Mennonites and Hutterites) is documented only once every ten years. The 2001 census published by Statistics Canada (available on-line at http://www.statcan.gc.ca/), ${ }^{15}$ was used to obtain the relative frequencies of various ethnicities and religions in children less than 15 years-of-age living in the province of Manitoba. The 2001 census year was chosen because it was near the middle of our study period and also because statistics on religions were available for that census year. The age group of children less than 15 years was considered a close match for our study cohort. For the more common diseases found in our cohort (defined arbitrarily as being present in at least four patients), exact logistic regression was conducted to determine the likelihood of disease (odds ratio and $95 \%$ confidence interval) according to ethnicity. Patients were classified according to the following ethnic groups: Aboriginal (all types or First Nations only), Hutterite, Mennonite, Caucasian, or "all others" (including Africans/Caribbean, Indian, Asian, mixed, and unknown ethnicity). The reference group comprised Caucasian children (both parents are Caucasian) who were not Mennonite or Hutterite to the best of our knowledge. In order to minimize the effect of disease clustering among first degree relatives, the analyses were repeated after excluding sibling pairs (only the first presenting sibling was retained; there were ten sibling pairs in the cohort). Statistical analyses were conducted using SAS 9.1 (SAS Institute Inc., Cary, NC, USA); results were considered significant when $\mathrm{p}<0.05$.

\section{RESUlts}

Of the 184 patients that satisfied the inclusion criteria of this study, half were males and 177 resided in Manitoba with many $(\mathrm{N}=96)$ living in Winnipeg, the provincial capital. Mean age (SD, range) at the end of the study was 15 (7.6, 1.1-34.1) years. Detailed stratification of the cohort by age and gender and other demographic information has already been published elsewhere. ${ }^{14}$ Geographic clustering of patients was uncommon (Figure). Only a few patients clustered in the small towns of Steinbach (N=9), which is $66 \mathrm{~km}$ south east of Winnipeg, and Morden/ Winkler $(\mathrm{N}=6)$, which are neighboring towns located $133 \mathrm{~km}$ south west of Winnipeg. These patients were mostly Mennonite, which is expected since these communities have a high population of Mennonites.

In our cohort of patients living in Manitoba, 62 were fully or partially Caucasian (both parents in 46 patients, one parent in 13 with the other parent's ethnicity being unknown, and mixed, i.e. one parent is Caucasian while the other parent is of another nonAboriginal race, in 3). Another 35 patients were Aboriginals, 29 


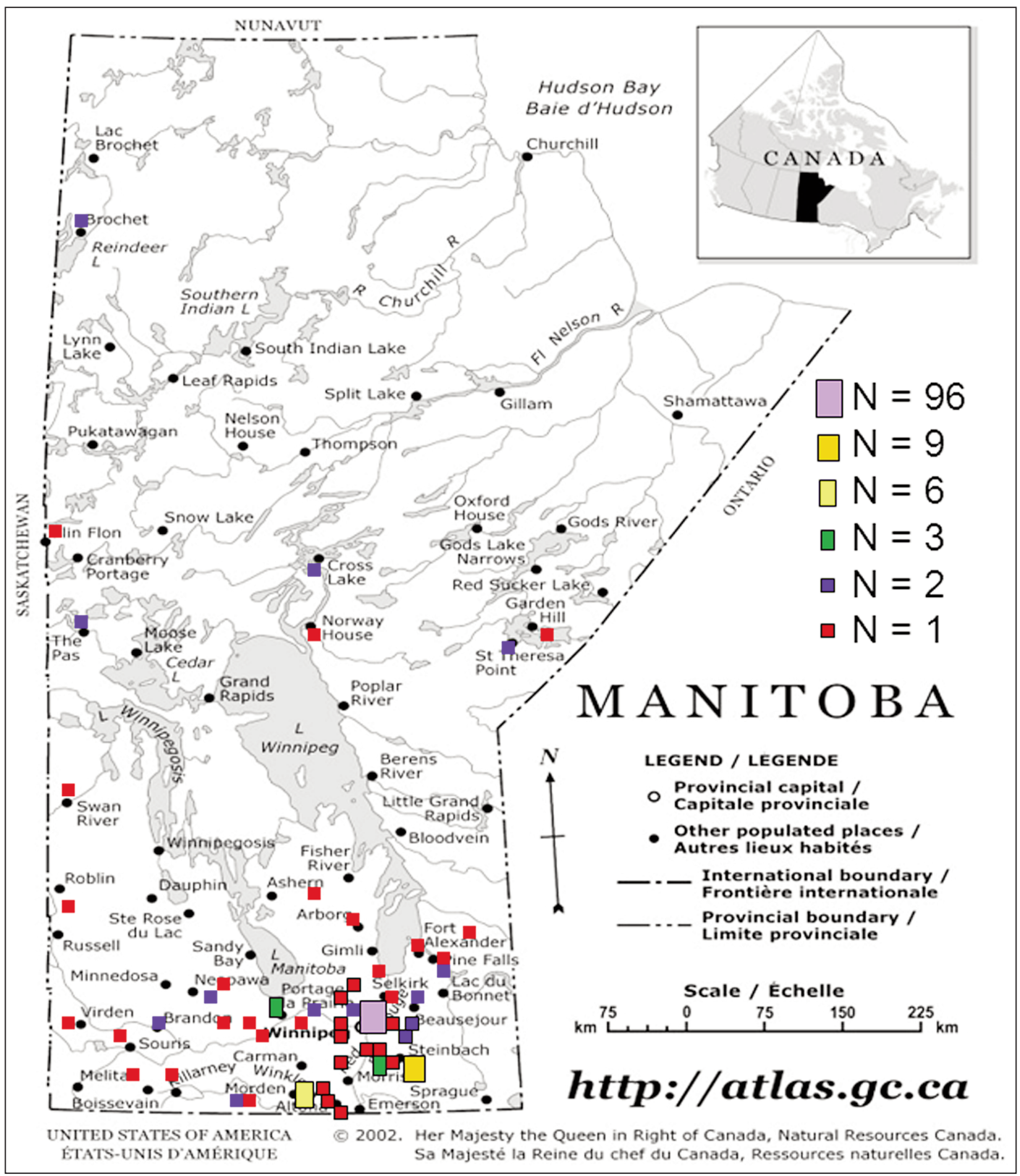

Figure: Map of the province of Manitoba, Canada showing the geographic distribution of pediatric patients $(N=177)$ with chronic ataxia during the period 1991-2008. ' $N$ ' denotes the number of patients represented by the colored squares (not drawn to scale) displayed on the map. Map source: (C) Department of Natural Resources Canada. All rights reserved.

were Mennonites, and 11 were Hutterites. The proportion of Mennonite and Hutterite patients in our cohort (16.4\% and 6.2\%, respectively) was significantly higher than anticipated in comparison to the pediatric population at risk living in the province (estimated at $5.1 \%$ and $1.3 \%$ according to the national census) (Table 1). ${ }^{15}$

The likelihood of each disorder according to ethnicity (compared to Caucasian) is shown in Table 1 for Manitoba residents $(\mathrm{N}=177)$, while the ethnicities among the more common disorders in the whole cohort $(\mathrm{N}=184)$ are displayed in Tables 2 and 3. There were 16 patients with Angelman syndrome. Most had Caucasian parents and four were Aboriginal; no significant differences according to ethnicity were observed. Mennonites were significantly overrepresented among patients with ataxia telangiectasia and mitochondrial disorders $(\mathrm{p}<0.001$ and $\mathrm{p}<0.01$, respectively). Ten of $13(76.9 \%)$ patients with ataxia telangiectasia were Mennonite, including one pair of siblings. Six patients resided in Steinbach. The nine patients with mitochondrial disorders resided in several cities and towns in and around Winnipeg. The furthest town was located $250 \mathrm{~km}$ west of Winnipeg. Three of the nine patients were Mennonite and had abnormalities in respiratory chain enzyme complexes I, IV, or both. There was no obvious geographic clustering. The other six non-Mennonite patients with mitochondrial disorders had Alpers disease, MELAS (mitochondrial encephalomyopathy, lactic acidosis and strokelike episodes), Leigh syndrome, respiratory enzyme complexes I 
Table 1: Likelihood of disorders associated with the more common causes of pediatric chronic ataxia $\neq$ according to ethnicity

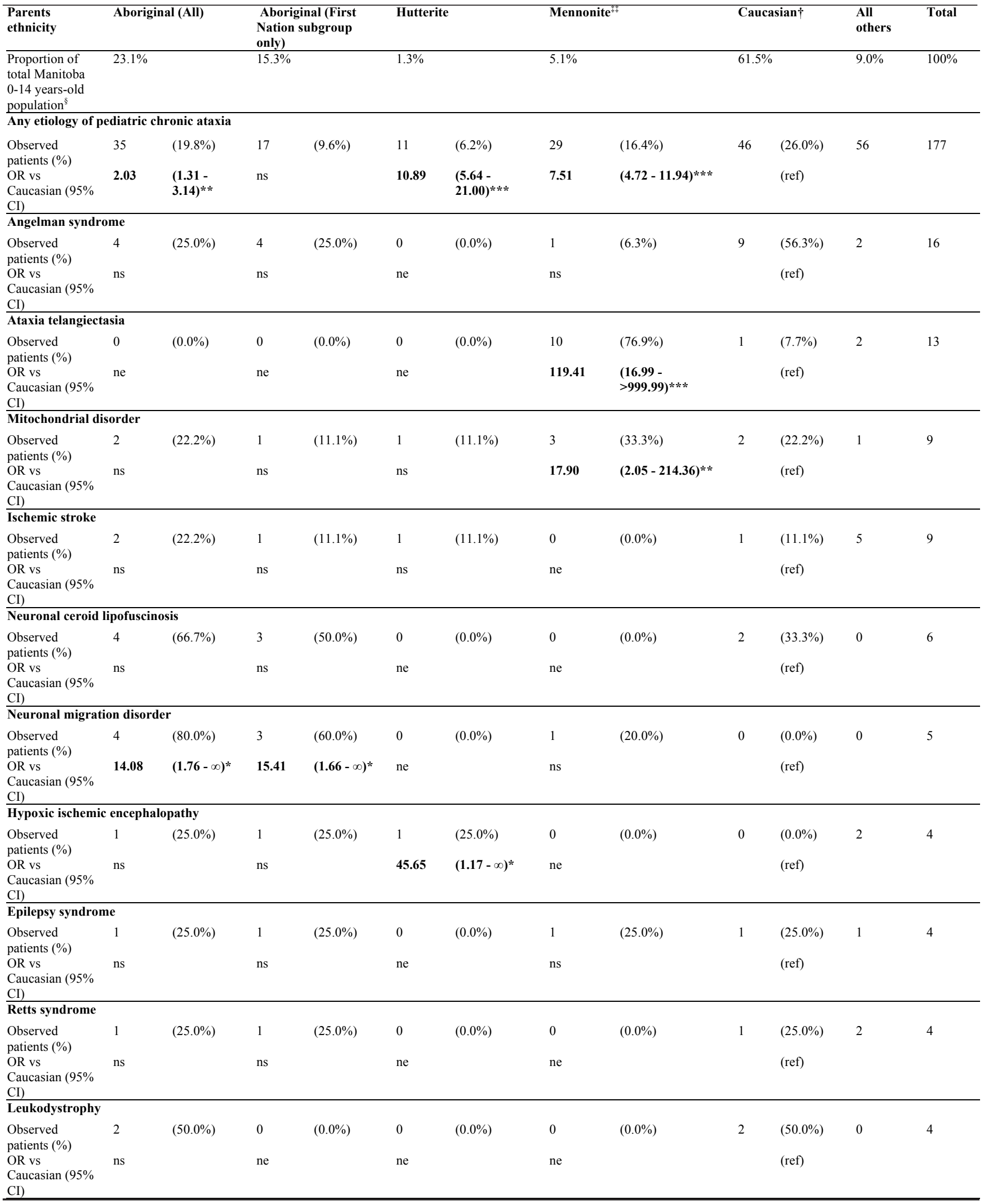


Table 1: Likelihood of disorders associated with the more common causes of pediatric chronic ataxia $\neq$ according to ethnicity (continued)

\begin{tabular}{|c|c|c|c|c|c|c|c|c|c|c|c|c|}
\hline \multicolumn{13}{|c|}{ Joubert syndrome and related disorders } \\
\hline $\begin{array}{l}\text { Observed } \\
\text { patients (\%) } \\
\text { OR vs } \\
\text { Caucasian (95\% } \\
\text { CI) }\end{array}$ & $\begin{array}{l}0 \\
\text { ne }\end{array}$ & $(0.0 \%)$ & $\begin{array}{l}0 \\
\text { ne }\end{array}$ & $(0.0 \%)$ & $\begin{array}{l}2 \\
110.23\end{array}$ & $\begin{array}{l}(50.0 \%) \\
(8.57- \\
\infty)^{* * *}\end{array}$ & $\begin{array}{l}1 \\
\mathrm{~ns}\end{array}$ & $(25.0 \%)$ & 0 & $\begin{array}{l}(0.0 \%) \\
(\mathrm{ref})\end{array}$ & 1 & 4 \\
\hline \multicolumn{13}{|c|}{$\begin{array}{l}\text { Disorders associated with a non progressive chronic ataxia of unknown etiology in the pediatric population } \\
\text { 1) Non progressive cerebellar syndrome of unknown etiology with developmental delay and pyramidal tract signs }\end{array}$} \\
\hline $\begin{array}{l}\text { Observed } \\
\text { patients (\%) } \\
\text { OR vs } \\
\text { Caucasian }(95 \% \\
\text { CI) } \\
\end{array}$ & 4 & $(18.2 \%)$ & $\begin{array}{l}2 \\
\mathrm{~ns}\end{array}$ & $(9.1 \%)$ & 1 & $(4.5 \%)$ & $\begin{array}{l}8 \\
31.84\end{array}$ & $\begin{array}{l}(36.4 \%) \\
(\mathbf{7 . 6 4}-\mathbf{1 8 6 . 3 5})^{* * *}\end{array}$ & 3 & $\begin{array}{l}(13.6 \%) \\
(\mathrm{ref})\end{array}$ & 6 & 22 \\
\hline \multicolumn{13}{|c|}{ 2) Non progressive cerebellar syndrome of unknown etiology with developmental delay, epilepsy and pyramidal tract signs } \\
\hline $\begin{array}{l}\text { Observed } \\
\text { patients (\%) }\end{array}$ & 1 & $(14.3 \%)$ & 0 & $(0.0 \%)$ & 1 & $(14.3 \%)$ & 0 & $(0.0 \%)$ & 3 & $(42.9 \%)$ & 2 & 7 \\
\hline $\begin{array}{l}\text { OR vs } \\
\text { Caucasian }(95 \% \\
\text { CI) }\end{array}$ & ns & & ne & & ns & & ne & & & (ref) & & \\
\hline \multicolumn{13}{|c|}{ 3) Non progressive cerebellar syndrome of unknown etiology with developmental delay } \\
\hline $\begin{array}{l}\text { Observed } \\
\text { patients }(\%)\end{array}$ & 3 & $(60.0 \%)$ & 1 & $(20.0 \%)$ & 0 & $(0.0 \%)$ & 0 & $(0.0 \%)$ & 1 & $(20.0 \%)$ & 1 & 5 \\
\hline $\begin{array}{l}\text { OR vs } \\
\text { Caucasian }(95 \% \\
\text { CI) }\end{array}$ & ns & & ns & & ne & & ne & & & (ref) & & \\
\hline \multicolumn{13}{|c|}{ 4) Non progressive cerebellar syndrome of unknown etiology with developmental delay and epilepsy } \\
\hline $\begin{array}{l}\text { Observed } \\
\text { patients }(\%)\end{array}$ & 1 & $(20.0 \%)$ & 0 & $(\%)$ & 1 & $(20.0 \%)$ & 0 & $(0.0 \%)$ & 0 & $(0.0 \%)$ & 3 & 5 \\
\hline $\begin{array}{l}\text { OR vs } \\
\text { Caucasian }(95 \% \\
\text { CI) }\end{array}$ & ns & & ne & & 45.65 & $(1.17-\infty)^{*}$ & ne & & & (ref) & & \\
\hline
\end{tabular}

部efined by the presence of at least four patients with the same disease group; ${ }^{\ddagger}$ At least one parent is Mennonite; ${ }^{\dagger}$ Caucasian reference group includes children who are known to have two Caucasian parents that are not Hutterite or Mennonite. Children who have only one Caucasian parent, other ethnicities, and unknown ethnicities are included in the "All others" column, ${ }^{\S}$ Statistics Canada 2001 census data. *p $<0.05$, ${ }^{* *} \mathrm{p}<0.01, * * * \mathrm{p}<0.001$ (shown in bold), OR, odds ratio; CI, confidence interval; ne, not estimable (due to 0 patients); ref, reference group. Non-significant associations (ns) not shown.

and IV deficiency, pyruvate carboxylase deficiency, and an uncharacterized mitochondrial disorder.

Six of seven patients with Friedreich ataxia had at least one Caucasian parent. There were two pairs of siblings with Friedreich ataxia. In addition, two pairs of siblings had acetazolamide responsive episodic ataxia. Of the nine patients with ischemic stroke associated with chronic ataxia, two resided in Winnipeg and another two resided $60 \mathrm{~km}$ south east of Winnipeg while the others were scattered in small towns.

Of the six patients with neuronal ceroid lipofuscinosis, four were Aboriginal (three First Nation and one Metis), but this did not represent a statistically significant association (Table 1). Two of these four were siblings and three of the four resided about $800 \mathrm{~km}$ north of Winnipeg. No geographic clustering was noted among the other patients. There were five patients including one pair of siblings with neuronal migration disorder involving the cerebral hemispheres associated with chronic ataxia. Four were Aboriginal and thus a statistically significant association was found between the disorder and the patients' ethnicity $(\mathrm{p}<0.05$, see Table 1). Three were First Nations and one Metis. Two resided in Winnipeg and two resided $120 \mathrm{~km}$ north east of Winnipeg.

Two of the four patients with leukodystrophy associated with chronic ataxia were siblings who had Cree leukodystrophy (synonymous with vanishing white matter leukodystrophy) and resided in the very far north of the province while the other two were Caucasians and resided in two towns west and far north of Winnipeg. One had X-linked adrenoleukodystrophy and the other had the presumptive diagnosis of Pelizaeus-Merzbacher disease.

The diagnosis was unknown in 56 of 184 patients with chronic ataxia, 41 of whom had a non progressive disease course. The other 15 patients were made up of clinically heterogeneous small groups of patients with intermittent or progressive ataxia of unknown etiology. The 41 patients were divided into several subgroups depending on the presence or absence of associated clinical features e.g., epilepsy and pyramidal tract signs. Abnormal pyramidal tract signs included hypertonia, hyper-reflexia, clonus, and Babinski's response. Table 4 shows the ethnicity among these subgroups for the whole of our cohort. The subgroups were as follows: 1) Twenty two of the 41 patients had a combination of developmental delay, cerebellar and pyramidal tracts sign(s). The disorder was significantly more common in Mennonite patients $(\mathrm{p}<0.001$, Table 1), 2) Seven of the 41 patients had developmental delay, epilepsy, cerebellar and pyramidal tracts signs, 3) Five of the 41 patients in this subgroup had cerebellar signs and developmental delay only. There was one pair of siblings in this subgroup, 4) 
Table 2: Ethnicity among the more common causes of pediatric chronic ataxia $\neq$ for the whole cohort $(\mathrm{N}=184)$

\begin{tabular}{|c|c|c|c|c|c|c|c|}
\hline Parents ethnicity & $\begin{array}{l}\text { Angelman } \\
\text { syndrome }\end{array}$ & AT & MD & $\begin{array}{l}\text { Ischemic } \\
\text { stroke }\end{array}$ & FA & $\begin{array}{l}\text { Acetazolamide } \\
\text { responsive episodic } \\
\text { ataxia }\end{array}$ & $\begin{array}{l}\text { Intermittent ataxia of } \\
\text { unknown etiology }\end{array}$ \\
\hline Total & 16 & 13 & 9 & 9 & 7 & 7 & 6 \\
\hline Both Caucasians & 9 & 1 & 2 & 1 & $3^{\dagger}$ & $4^{\S}$ & 4 \\
\hline One Caucasian & 1 & & & 1 & $3^{\dagger}$ & 1 & \\
\hline Both Mennonites & & $9^{\dagger}$ & 2 & & & & \\
\hline One Mennonite & 1 & 1 & 1 & & & & \\
\hline Hutterites & & & 1 & 1 & & & \\
\hline Aboriginals & $4 \mathrm{FN}$ & & $1 \mathrm{FN}, 1$ & $1 \mathrm{FN}, 1$ & 1 Metis & & \\
\hline & & & Metis & Metis & & & \\
\hline Unknown & & & 1 & 4 & & 2 & 2 \\
\hline African/ Caribbean & 1 & & & & & & \\
\hline Asians & & 2 & & & & & \\
\hline
\end{tabular}

‡Defined by the presence of at least four patients with the same disease group; †includes one pair of siblings; \$two pairs of siblings AT, ataxia telangiectasia; MD, mitochondrial disorder; FA, Friedreich ataxia; FN, First Nation

Table 3: Ethnicity among other common causes of pediatric chronic ataxia $\neq$ for the whole cohort $(\mathrm{N}=184)$

\begin{tabular}{|c|c|c|c|c|c|c|c|}
\hline Parents ethnicity & NCL & $\begin{array}{l}\text { Epilepsy } \\
\text { syndrome }\end{array}$ & HIE & $\begin{array}{l}\text { Neuronal migration } \\
\text { disorder }\end{array}$ & $\begin{array}{l}\text { Retts } \\
\text { syndrome }\end{array}$ & $\mathbf{J S}$ & LD \\
\hline Total & 6 & 5 & 5 & 5 & 4 & 4 & 4 \\
\hline Both Caucasians & 2 & 1 & & & 1 & & 2 \\
\hline One Caucasian & & & & & 1 & & \\
\hline Both Mennonites & & 1 & & 1 & & 1 & \\
\hline One Mennonite & & & & & & & \\
\hline Hutterites & & & 1 & & & 2 & \\
\hline Aboriginals & $\begin{array}{l}3 \mathrm{FN}^{\dagger}, 1 \\
\text { Metis }\end{array}$ & $2 \mathrm{FN}^{*}$ & $1 \mathrm{FN}^{*}, 1 \mathrm{Ab}$ & $4\left(3 \mathrm{FN}^{\dagger}, 1 \mathrm{Metis}^{\S}\right)$ & $1 \mathrm{FN}$ & & $2 \mathrm{Metis}^{\dagger \S}$ \\
\hline $\begin{array}{l}\text { Unknown } \\
\text { Indians }\end{array}$ & & 1 & 2 & & 1 & 1 & \\
\hline
\end{tabular}

₹Defined by the presence of at least four patients with the same disease group; ${ }^{\dagger}$ includes (or they are) one pair of siblings; * one patient lives outside Manitoba; ${ }^{\S}$ one of the parent is FN and the other is Metis. NCL, neuronal ceroid lipofuscinosis; HIE, hypoxic ischemic encephalopathy; LD, leukodystrophy; JS, Joubert syndrome related disorder; FN, First Nation; Ab, dad is FN and mom is Aboriginal but type is unknown

Table 4: Ethnic distribution among the 41 (of 184) patients with non progressive disorders associated with pediatric chronic ataxia

\begin{tabular}{|c|c|c|c|c|c|}
\hline \multirow[b]{2}{*}{ Parents ethnicity } & \multicolumn{5}{|c|}{ Disorders with cerebellar signs associated with: } \\
\hline & $\underline{\mathrm{UMN}} \operatorname{sign}(\mathrm{s})$ and DD & $\begin{array}{l}\text { Epilepsy, one UMN sign } \\
\text { and DD }\end{array}$ & DD only & $\begin{array}{l}\text { Epilepsy and } \\
\text { DD }\end{array}$ & $\begin{array}{l}\text { No other } \\
\text { features }\end{array}$ \\
\hline Total & 22 & 7 & 5 & 5 & 2 \\
\hline Both Caucasians & 3 & 3 & 1 & & \\
\hline One Caucasian & 1 & 1 & 1 & 2 & \\
\hline Both Mennonites & 4 & & & & 1 \\
\hline One Mennonite & 4 & & & & \\
\hline Hutterites & 1 & 1 & & 1 & \\
\hline Aboriginals & $2 \mathrm{FN}^{* \dagger}, 2$ Metis & 1 Metis & $1 \mathrm{FN}^{\S}, 2$ Metis & 1 Metis & \\
\hline Indian & 1 & & & & \\
\hline Unknown & 4 & 1 & & 1 & 1 \\
\hline
\end{tabular}

${ }^{*}$ One patient moved later on to another province within Canada; ${ }^{\dagger}$ one of these two patients, who lives in Manitoba has a sibling marked as ${ }^{\S}$ UMN, upper motor neuron; DD, developmental delay; FN, First Nation 
Five of the 41 patients had developmental delay, epilepsy and cerebellar signs, and 5) Two of 41 patients had cerebellar signs only.

Although based on very few patients, three disorders appeared to be statistically more common in the Hutterite population (Table 1). The first was a Joubert syndrome related disorder in two patients, the second was hypoxic ischemic encephalopathy in a single patient, and the third was a nonprogressive cerebellar motor syndrome associated with developmental delay and epilepsy of unknown etiology in another single patient.

The results of all the analyses in Table 1 were similar after excluding sibling pairs (data not shown).

\section{Discussion}

Genetic disorders within defined ethnic groups may show strong founder effects, or may have multiple origins even within small geographic areas. ${ }^{4,5,9,13}$ Factors influencing these patterns include the mutation rate for specific genes, the age of the examined mutations, and the degree of isolation of the investigated community from other ethnic groups. ${ }^{1}$ The ability to identify carriers in this population facilitates genetic counseling and biomedical research, and enables epidemiologists to correlate any carrier susceptibility risks. ${ }^{3,5}$ Adequate counseling and support should accompany such testing in the event that a correlation is found.

The prevalence of pediatric chronic ataxia varied across different ethnicities in our province. Angelman syndrome has been reported in both genders and in individuals of diverse ethnic backgrounds. Our study revealed Angelman syndrome to be most common in non-Mennonite or Hutterite Caucasians, who represent the majority of the Manitoba population, which is consistent with another study. ${ }^{16}$ No excess patients were found in the Aboriginal population.

Mennonite patients were significantly over represented in our cohort of patients with chronic ataxia. Mennonites are a religious and genetic isolate of 16th century Dutch/ German ancestry. This group moved to Canada over the past 100 years. ${ }^{17}$ Many patients in our cohort with Ataxia telangiectasia were Mennonites, which may be due to a common founder effect. ${ }^{17,18}$ A significantly higher proportion of Mennonite patients had mitochondrial disorders. This is consistent with other studies that reported higher prevalence of different mitochondrial disorders in the Mennonite population, which have been reviewed elsewhere. ${ }^{17}$ Among the patients with chronic ataxia whose disease etiology remains unknown, we identified several with a non-progressive cerebellar motor syndrome associated with pyramidal tract signs and developmental delay, which was more frequent in Mennonite patients. This deserves further investigation.

Friedreich ataxia is reported in individuals of European, North American, Middle Eastern or Indian origin. ${ }^{19}$ This is consistent with our study results. The neuronal ceroid lipofuscinoses are a group of progressive neurodegenerative disorders, which are usually recessively inherited. There is a high prevalence of neuronal ceroid lipofuscinosis in the Canadian province of Newfoundland, which may be due to social isolation and the founder effect. ${ }^{20,21}$ Four of our six patients with this diagnosis were Aboriginal and three of these four (including one sibling pair) were Cree from one northern region in the province.
This apparent higher incidence was not statistically significant. Neuronal migration disorders associated with chronic ataxia occurred mostly among Aboriginal pediatric patients in our cohort. No such association has been reported previously.

There were a significantly higher proportion of Hutterite patients in our cohort. The association with a Joubert syndrome related disorder has already been described in the Hutterite population. $^{22}$ However, the other two disease associations reported in this paper affected only single patients. Therefore, the statistical significance of the two associations is of uncertain clinical significance. In addition, there were two Hutterite patients in our cohort, who had autosomal recessive cerebellar hypoplasia in the Hutterites population (disequilibrium syndrome), which has already been characterized in this population. ${ }^{12}$

Findings in this study were not significantly affected by the ten sibling pairs since the results were unchanged after siblings were excluded on a subanalysis.

Our study limitations include incomplete ascertainment of patients with chronic ataxia, although this is unlikely since our center is the only tertiary pediatric facility in the province where such patients are assessed. ${ }^{14} \mathrm{We}$ also encountered missing, incomplete and inaccurate information recorded in the hospital chart including information on ethnicity. In addition, our study is hospital rather than community based. Finally, the actual prevalence of known disease etiologies may be higher since the ability to make definitive diagnoses improved significantly over the 18 year study period with more medical advances. The effects of these limitations on our study results are likely minimal as discussed previously. ${ }^{14}$

In conclusion, the prevalence of pediatric chronic ataxia was variable across ethnic groups in Manitoba, Canada. A few disease-specific clusters were identified in the Mennonite, Hutterite, and Aboriginal populations. Further research is needed to understand the risk factors underlying these variations in prevalence within certain ethnic groups. The unique risk factor profiles of each ethnic group need to be considered during health promotion activities.

\section{ACKNOWLEDGEMENTS}

The authors thank V. Harari for her help in mapping some of the data. They also thank the Manitoba Medical Service Foundation and Braden Hope Fund for their financial support, as well as The Manitoba Institute of Child Health and The Children Hospital Foundation of Manitoba for providing the infrastructure needed for the project and for financial support. We thank T. Styba for performing part of the data collection. 


\section{REFERENCES}

1. Sequeiros J, Martins S, Silveira I. Epidemiology and population genetics of degenerative ataxias. Handb Clin Neurol. 2012;103: 227-51.

2. Werdelin L, Keiding N. Hereditary ataxias: epidemiological aspects. Neuroepidemiology. 1990;9(6):321-31.

3. Collins SA, Sinclair G, McIntosh S, et al. Carnitine palmitoyltransferase 1A (CPT1A) P479L prevalence in live newborns in Yukon, Northwest Territories, and Nunavut. Mol Genet Metab. 2010;101(2-3):200-4.

4. Greenberg CR, Dilling LA, Thompson GR, et al. The paradox of the carnitine palmitoyltransferase type Ia P479L variant in Canadian Aboriginal populations. Mol Genet Metab. 2009;96 (4):201-7.

5. Morton DH, Morton CS, Strauss KA, et al. Pediatric medicine and the genetic disorders of the Amish and Mennonite people of Pennsylvania. Am J Med Genet C Semin Med Genet. 2003;121C (1):5-17.

6. Thomson AK, Glasson EJ, Bittles AH. A long-term populationbased clinical and morbidity profile of Angelman syndrome in Western Australia: 1953-2003. Disabil Rehabil. 2006;28(5): 299-305.

7. Tsuji S, Onodera O, Goto J, Nishizawa M, on behalf of the study group on ataxic diseases. Sporadic ataxias in Japan - a population-based epidemiological study. Cerebellum. 2008;7(2): 189-97.

8. Palau F, Espinós C. Autosomal recessive cerebellar ataxias. Orphanet J Rare Dis. 2006;1:47.

9. Erichsen AK, Koht J, Stray-Pedersen A, Abdelnoor M, Tallaksen CME. Prevalence of hereditary ataxia and spastic paraplegia in southeast Norway: a population-based study. Brain. 2009;132(Pt 6): $1577-88$

10. Anheim M, Fleury M, Monga B, et al. Epidemiological, clinical, paraclinical and molecular study of a cohort of 102 patients affected with autosomal recessive progressive cerebellar ataxia from Alsace, Eastern France: implications for clinical management. Neurogenetics. 2010;11(1):1-12.

11. Sridharan R, Radhakrishnan K, Ashok PP, Mousa ME. Prevalence and pattern of spinocerebellar degenerations in northeastern Libya. Brain. 1985;108( Pt 4):831-43.
12. Boycott KM, Flavelle S, Bureau A, et al. Homozygous deletion of the very low density lipoprotein receptor gene causes autosomal recessive cerebellar hypoplasia with cerebral gyral simplification. Am J Hum Genet. 2005;77(3):477-83.

13. Dupré N, Bouchard JP, Brais B, Rouleau GA. Hereditary ataxia, spastic paraparesis and neuropathy in the French-Canadian population. Can J Neurol Sci. 2006;33(2):149-57.

14. Salman MS, Lee EJ, Tjahjadi A, Chodirker BN. The epidemiology of intermittent and chronic ataxia in children in Manitoba, Canada. Dev Med Child Neurol. 2013;55(4):341-7.

15. Statistics Canada, 2001 Census of population of Canada, provinces, territories (data products, topic-based tabulations) catalogues no. 95F0300XCB2001004, 97F0022XCB2001002, 97F0011XCB 2001002, 95F0363XCB2001003 (Manitoba, Code 46). Ottawa, Ontario: Statistics Canada. Available from: http://www12. statcan.ca/english/census01/products/standard/themes/indexeng.cfm (accessed December 24th 2012).

16. Buckley RH, Dinno N, Weber P. Angelman syndrome: are the estimates too low? Am J Med Genet. 1998;80(4):385-90.

17. Orton NC, Innes AM, Chudley AE, Bech-Hansen NT. Unique disease heritage of the Dutch-German Mennonite population. Am J Med Genet A. 2008;146A(8):1072-87.

18. Telatar M, Teraoka S, Wang Z, et al. Ataxia-Telangiectasia: identification and detection of founder-effect Mutations in the ATM gene in ethnic populations. Am J Hum Genet. 1998;62: 86-97.

19. Labuda M, Labuda D, Miranda C, et al. Unique origin and specific ethnic distribution of the Friedreich ataxia GAA expansion. Neurology. 2000;54(12):2322-4.

20. Moore SJ, Buckley DJ, MacMillan A, et al. The clinical and genetic epidemiology of neuronal ceroid lipofuscinosis in Newfoundland. Clin Genet. 2008;74:213-22.

21. VAMP1 mutation causes dominant hereditary spastic ataxia in Newfoundland families. Bourassa CV, Meijer IA, Merner ND, et al. Am J Hum Genet. 2012;91(3):548-52.

22. Boycott KM, Parboosingh JS, Scott JN, et al. Meckel syndrome in the Hutterite population is actually a Joubert-related cerebellooculo-renal syndrome. Am J Med Genet A. 2007;143A(15): 1715-25. 